\title{
Ti6Al4V Surface Modification by Hydroxyapatite Powder Mixed Electrical Discharge Machining for Medical Applications
}

\author{
Tıbbi Uygulamalar için Hidroksiapatit Toz Katkılı Elektro Erozyon İşleme ile Ti6Al4V Yüzey \\ Modifikasyonu
}

\author{
Tahsin Tecelli ÖPÖZ1 ${ }^{1}$, Hamidullah YAŞAR ${ }^{2} \mathbb{D}$, Mark Francis MURPHY $^{3} \mathbb{D}$, Nihal EKMEKCí2 $^{\mathbb{D}}$, \\ Bülent EKMEKCi'² \\ ${ }^{1}$ Liverpool John Moores University, General Engineering Research Institute, L3 3AF, Liverpool, UK. \\ ${ }^{2}$ Bulent Ecevit University, Department of Mechanical Engineering, 67100, Zonguldak, Turkey. \\ ${ }^{3}$ Liverpool John Moores University, School of Pharmacy and Biomolecular Sciences, L3 3AF, Liverpool, UK.
}

\begin{abstract}
Titanium surface modification by the Hydroxyapatite (HA) mixed Electrical Discharge Machining (EDM) is an alternative and promising technique to enhance the biocompatibility and to promote the biological performance in bone, which is dependent on surface properties, such as surface roughness, chemistry, and wettability. HA powder is used for the first time with electrical discharge machining to improve osteoblastic cell activity on the developed surfaces for Ti6A14V. Different HA concentrations in deionized water were tested as an experimental variable during EDM. Abrasive polishing and electrical discharge machined control surfaces without powder addition also analyzed to compare the results. The surface characteristics of analyzed samples were evaluated by Scanning Electron Microscopy (SEM), Energy Dispersive Spectroscopy (EDS), X-Ray Diffractometry (XRD), white light interferometry, and contact angle measurements. The wettability tests suggest that the hydroxyapatite powder mixed EDM'ed surfaces shows highly hydrophilic characteristics compared the other surfaces, abrasive polished and EDM'ed without powder addition in the dielectric. The results from the MTT assay revealed that those surfaces modified using HA powder addition in distilled water dielectric liquid promoted the most significant cell attachment/growth. The results indicate that HA powder mixed EDM offers a promising method for the surface modification of biomaterials such as titanium alloys.
\end{abstract}

Keywords: Ti6A14V, Surface modification, Hydroxyapatite, Powder mixed electrical discharge machining, Osteoblast, Cell attachment and growth.

$\ddot{\mathbf{O z}}$

Hidroksiapatit (HA) katkılı Elektro Erozyon İşleme (EEİ) ile Titanyum yüzey modifikasyonu, yüzey pürüzlülüğü, yüzey kimyasi, 1slatılabilirlik gibi yüzey özelliklerine bağlı olan kemikte biyolojik performans ve uyumluluğun arttırılması için alternatif ve gelecek vaat eden bir tekniktir. HA tozu katkılı elektro erozyon ile işlenen Ti6A14V yüzeyler, osteoblastik hücre aktivitesini geliştirmek için ilk kez bu çalışmada kullanılmıştır. Deiyonize sudaki farklı HA konsantrasyonları EEİ sırasında deneysel bir değişken olarak test edildi. Zımparalanmış ve toz ilavesi olmadan elektro erozyon ile işlenmiş kontrol yüzeyleri, karşılaştırma amaçli kullanılmıstır. Analiz edilen numunelerin yüzey özellikleri Taramalı Elektron Mikroskobu (SEM), Enerji Dağılım Spektroskopisi (EDS), X-Işını Difraktometrisi (XRD), beyaz 1şık interferometrisi ve temas açısı ölçümleri ile değerlendirildi. Islatılabilirlik testleri, hidroksiapatit toz katkili EEI'nin yüzeylerinin diğer yüzeylere kıyasla daha yüksek hidrofilik özellik sergilediğini göstermektedir. MTT testinden elde edilen sonuçlar, HA tozu katkılı damıtılmış su kullanılarak modifiye edilmiş yüzeylerin önemli derecede hücre bağlanma ve büyümesini desteklediğini göstermiştir. Sonuçlar, HA tozu katkili EEI 'nin, titanyum alaşımları gibi biyomalzemelerin yüzey modifikasyonu için umut verici bir yöntem oldugunu göstermektedir.

Anahtar Kelimeler: Ti6A14V, Yüzey modifikasyonu, Hidroksiapatit, Toz katk1lı elektro erozyon ile işleme, Osteoblastik, Hücre bağlanmas1 ve büyümesi. 


\section{INTRODUCTION}

Recently, the importance of biomaterials has been increasing in parallel with the developments of medicine and engineering. These materials used for the repair of injuries, inflammations, tumors, gangrene, implants and could be metals, ceramics, polymers, and composites. The most commonly used metals for such applications are $\mathrm{Ti}$ and $\mathrm{Ti}$ alloys, as well as stainless steel. Metals for biomedical applications are usually coated to prevent corrosion and metallic ion release that have possible toxic effects to biological being. Working on various coating methods, facilitate surface coating or obtain functional surfaces to inhibit such side effects of metals have become the focus of researchers. Nowadays Electrical Discharge Machining (EDM) is considered a challenging alternative for obtaining functional surfaces for medical applications. Especially the properties of the surface and subsurface layers obtained in the EDM method are worth investigating in this regard.

In general, the topmost layer on the EDM'ed surface is the resolidified structure generated due to the thermal actions of the sequentially applied sparks. The heat affected structures in solid state lay underneath the resolidified layer that is followed by the base material. The creation of the nano structural resolidified layer is vital for the development of biocompatibility. Formation of $\gamma$ phase and $\kappa$ carbide in recast layer observed when Fe-Al-Mn work material EDM'ed in kerosene dielectric liquid. Therefore, the formation of the nanostructure oxide layer in EDM could improve the work material biocompatibility [1]. Besides, nano $(\delta+\gamma)$ hydrides are also essential for the formation of nano structural oxide layers. $\alpha \rightarrow(\alpha+\delta) \rightarrow(\delta+\gamma) \rightarrow \gamma$ conversion occurs in resolidified layer throughout the EDM. Moreover, short duration pulses provide nano porous $\mathrm{TiO}_{2}$ on EDM'ed titanium surface [2]. Yang et al., [3] and Lee et al., [4] have observed nanoscale pores in anatase $\mathrm{TiO}_{2}$ surface when EDM of Ti-6Al-4V work material when using water as the dielectric liquid. Also, better biocompatible surfaces were obtained when using high pulse current and duration during EDM [5]. Fabrication of biocompatible microdevices is also possible by micro EDM with the desired surface roughness values recommended for biological applications [6]. Corrosion resistance is also a key factor for dental implant application. Comparison of EDM'ed and conventionally finished (grounded and polished) surfaces revealed a reduction in corrosion resistance of $\mathrm{Co}-\mathrm{Cr}$ and grade II cpTi alloys [7].

Obtaining functional surfaces with the aid of powder additives in dielectric liquid also compelled researchers interest.In this way, $\mathrm{TiC}$ and nickel enriched resolidified layers formed on the surface with the proper selection of powder additives [8]. $150 \mu \mathrm{m}$ thick TiC layer with a hardness of $1600 \mathrm{HV}$ on carbon steel is possible when using Ti powder additives in EDM [9]. Using reduced discharge energy improve the hardness of the resolidified layer up to $2000 \mathrm{HV}$ [10]. A titanium layer formed onto tungsten carbide work material when using Ti powder mixed EDM. The hardness of the layer reached up to $1750 \mathrm{HV}$ with fewer occasions of cracking on the surface [11]. Similarly, tungsten powder mixed EDM produced a tungsten-rich and hard-resolidified layer on steel [12]. SiC powder mixed EDM'ed Ti-6Al-4V surfaces also indicate material migration from the suspended dielectric liquid. [13]. Al powder provides the least surfaces roughness, the best surface topography, and material removal rate, followed by $\mathrm{SiC}, \mathrm{Gr}, \mathrm{Cr}$ and $\mathrm{Fe}$ in sequence in powder mixed EDM [14].The obtained recast layer can be considered as a kind of coating with excellent mechanical properties when tool steel is machined molybdenum powder mixed EDM[15]. Similarly, a continuous strengthened $\mathrm{TiC}$ and $\mathrm{TiSi}_{2}$ is formed on Ti-6Al-4V when using SiC abrasive-mixed EDM with magnetic stirring [16].

The literature survey above reveals the possibility of powder mixed EDM as an alternative technique for obtaining functional implant surfaces. Surface treatment of Ti6Al-4V alloy by EDM for orthopedics applications provided better substrates for the adhesion, growth, and viability of MG-63 cells than the alloy plasma-sprayed with $\mathrm{TiO}_{2}$ [17]. High current, pulse duration, and powder concentration in Powder Mixed EDM increase the recast layer thickness and provide a Ti modified hydrophilic surface without surface cracks [18]. Bioceramic oxides and carbide phases (TiC, $\mathrm{SiC}$, and $\mathrm{NbC}$ ) on the Powder Mixed EDM'ed $\beta$-Ti surface provide excellent adhesion to the substrate with improved hardness. Besides this, acceptable corrosion resistance is obtained for dental implants [19]. The fatigue endurance limit of $280 \mathrm{MPa}$ is possible which is very suitable for orthopedic applications [20]. Similarly, according to the multi-objective optimization results, parameter sequence consisting of 13 A peak current, $5 \mu$ s pulse duration, $8 \%$ duty factor and $8 \mathrm{~g} / \mathrm{l}$ powder concentration is the most suitable choice to enhance the biocompatibility of $\beta$-Ti alloy [21]. Surface crack density on the machined surface decrease considerably on EDM'ed Ti-35Nb-7Ta-5Zr $\beta$-titanium alloy when using $4 \mathrm{~g} / \mathrm{l} \mathrm{Si}$ powder concentration in the dielectric liquid. The pore size of $200-500 \mathrm{~nm}$ in the interconnected surface is obtainable in the parameter sequence consisting of $15 \mathrm{~A}$ pulse current, longer pulse interval and $8 \mathrm{~g}$ / 1 Si powder concentration [22]. Therefore, powder mixed EDM provides higher bone/implant interface strengths, nanoporous surface, suitable adhesion and growth of osteoblast-like cell (MG-63) [23]. 
Hydroxyapatite (HA) is one of the hardest molecules, and its crystal structure is similar to that of the human skeletal system so that it can be used instead of bone. Similar to the structure of the bone, the ratio of calcium to phosphorus $(\mathrm{Ca}$ ( P) is around 1.67. The studies on the use of HA for medical applications in powder mixed EDM were first carried out in 2013[24]. In their study, they performed HA precipitation on Ti alloy when using HA additives in the dielectric liquid. They showed that the most suitable parameters are high pulse current and low pulse on duration. In their continuing work, they have indicated that secondary sparks have made deposition more effectively [25]. Recent work on this subject has shown an improved corrosion resistance for $\beta$-phase Ti implant by HA mixed EDM. Higher corrosion resistance and improved hardness, as well as $18-20 \mu \mathrm{m}$, recast layer containing biocompatible phases with excellent adhesion to the base surface could be achieved [26]. Similarly, orthopedic-implant materials based on titanium and titanium-tantalum alloys are EDM'ed using HA powder additives [27]. In another study, a biocompatible and nanoporous hard layer is formed on metallic glass surface when using HA as a powder additive in hydrocarbon-based dielectric liquid [28].

The main attractive point of the process is the ability to provide extreme heat and pressure cycles in microscale that could not be achieved by other known techniques. Therefore, the idea of adding the powder in a dielectric liquid and modifying the machined surfaces for specific needs promising an innovative and practical alternative technique. Nowadays, among the specific needs, the possibility of generation of biocompatible surfaces with the use of the process became an attractive alternative to the known surface modification techniques such as plasma spray, shot peening, abrasive blasting, aqueous spray, and pulsed laser deposition. The studies are in the initial state, and preceding studies are needed to understand the bioactivity of HA powder mixed EDM. Therefore, the surface characteristics and biocompatibility of Ti6Al4V surfaces modified HA powder mixed EDM are analyzed in the study.

\section{EXPERIMENTAL SETUP AND PROCEDURE}

\subsection{Test Samples Preparation}

Ti-6Al-4V ELI (Grade 5 ELI) materials were used in this study. The samples with $8 \mathrm{~mm}$ length were cut from $10 \mathrm{~mm}$ diameter titanium rod. Samples were machined by using AJANEDM CNC983 brand die sink type EDM(Figure 1). Pure titanium was used as the tool electrode during EDM. Deionised water was used as a dielectric fluid. Hydroxyapatite (HA) powder was added to the water to obtain varying concentrations $(0,5,10$, and $15 \mathrm{~g} / \mathrm{L})$. Other EDM process parameters kept constant for all experiments. The machining condition was selected from the previous experimentation as $12 \mu$ s pulse on duration and $22 \mathrm{~A}$ pulse current [25]. As a control, two Ti samples were wet-abraded with \# 600 to \#1200 SiC abrasive paper followed by polishing with $1 \mu \mathrm{m}$ polishing cloth. One of the control surfaces was polished by keeping the orientation of the sample constant during polishing (direct polish) as shown in Figure 2(a), the other one was polished with random orientation (random polish) as shown in Figure 2(b). After machining, the samples were cleaned in acetone for $5 \mathrm{~min}$., ethanol for $5 \mathrm{~min}$., and pure water for 15 min., using an ultrasonic cleaner and the samples were dried in the air after each cleaning processes.

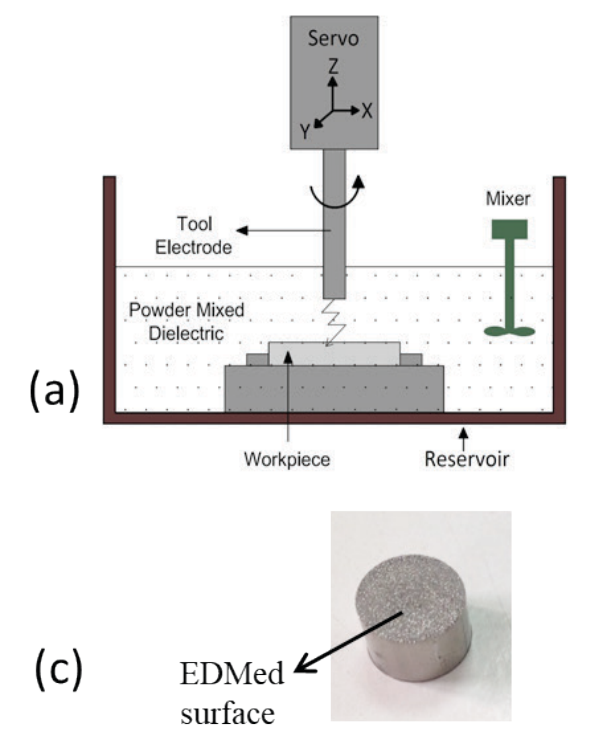

(b)

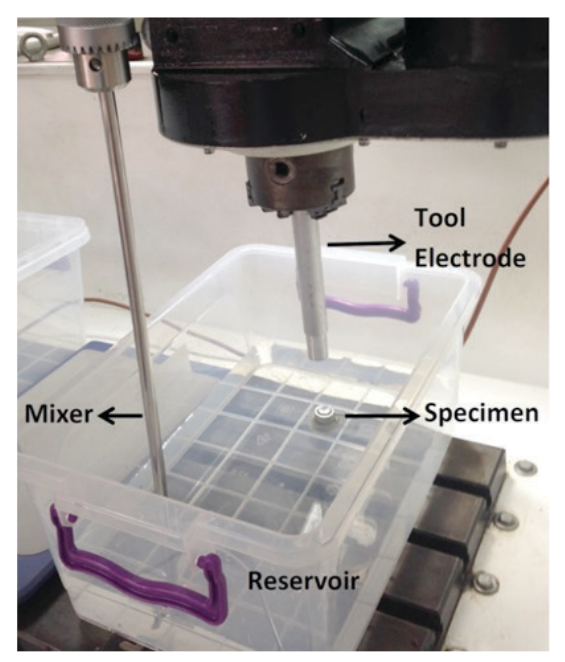

Figure 1. Experimental setup (a) schematic drawing, (b) reservoir view and (c) an EDMed sample. 


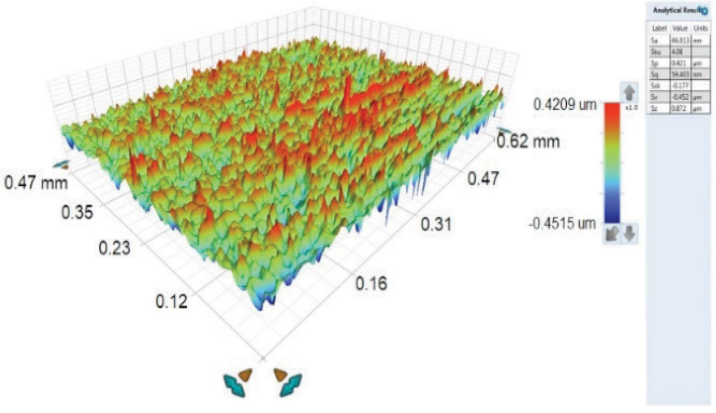

( a )

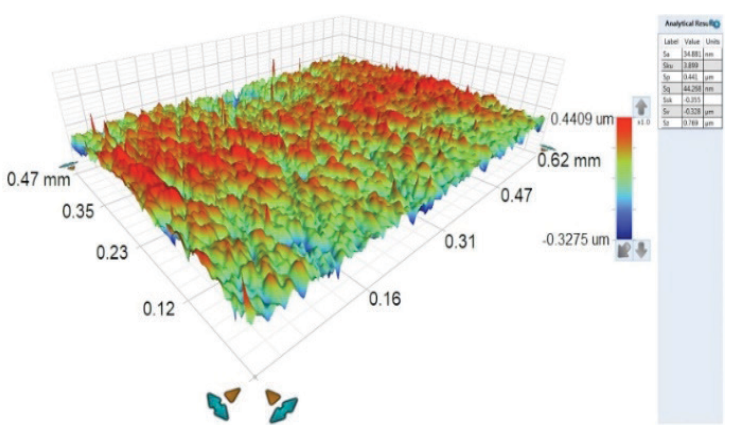

( b )

Figure 2. Control surfaces (a) directly polished $\left(\mathrm{S}_{\mathbf{a}}=61.5 \mathrm{~nm}\right)$ and $(\mathrm{b})$ randomly polished $\left(\mathrm{S}_{\mathbf{a}}=34.8 \mathrm{~nm}\right)$. $\mathrm{S}_{\mathbf{a}}$ is an areal surface roughness parameter measured using Bruker white light interferometer.

\subsection{Surface Analysis}

The surface morphologies and surface elemental composition of the EDMed samples were examined by using scanning electron microscopy (SEM, FEI Inspect S.) coupled with energy-dispersive x-ray spectroscopy (EDS). Phase composition of the EDMed surfaces were examined by using $\mathrm{X}$-ray diffractometer (XRD, RigakuMiniFlex) with settings $(\mathrm{Cu}, 30 \mathrm{kV}, 15 \mathrm{~mA})$. The samples were scanned at an incident angle over a $2 \theta$ range of $30^{\circ}$ to $90^{\circ}$. Bruker Contour GT-K $3 \mathrm{D}$ optical microscope (white light interferometer) with Vision 64 software was used for surface topography and surface roughness analysis. Average of three surface roughness measurement was taken to evaluate the results.

\subsection{Sessile-Drop Contact Angle Measurement}

The water contact angle of the samples was measured using a KSV CAM101 contact angle goniometer. Contact angle measurement conducted for $30 \mathrm{~s}$ time duration $(20 \mathrm{f} / \mathrm{s})$ for a single drop. Each drops volume during contact angle measurement was $1.5 \mu \mathrm{L}$. Mean value of the contact angle was obtained at $10 \mathrm{~s}$ when the water droplet got mostly stable form.

\subsection{Cell Culture}

The cells described in this work are human bone Fibroblast cells, MG-63 (ECACC 86051601), which were purchased from Public Health of England. All cell culture work was carried out under aseptic conditions in a grade II laminar flow cabinet (EBSCO). Cells were maintained at $37{ }^{\circ} \mathrm{C}$ in a humidified $5 \%$ CO2/95 \% air atmosphere in Dulbecco's modified Eagle's medium (DMEM) (Sigma Aldrich, D6429) supplemented with $10 \%$ foetal bovine serum (Sigma-Aldrich, 0804) and $1 \%$ penicillin-streptomycin.

\subsection{Cell Attachment and Growth}

To determine if the cells (MG-63) preferred a particular machined surface, they were seeded onto the surfaces at a density of 10,000 cells per well and left to incubate for $24 \mathrm{hrs}$ $\left(37^{\circ} \mathrm{C}, 5 \% \mathrm{CO} 2 / 95 \%\right.$ humidity). After $24 \mathrm{hrs}$, an MTT assay was carried out to determine relative cell growth on all surfaces through absorbance. Briefly, MTT (3-(4,5-dimethylthiazol-2-yl)-2,5-diphenyltetrazolium bromide) was added to the cells $(0.5 \mathrm{mg} / \mathrm{ml})$ and the cells left to incubate for 2 hours $\left(37^{\circ} \mathrm{C}, 5 \% \mathrm{CO} 2 / 95 \%\right.$ humidity). Next, $10 \%$ (v/v) DMSO was added to the cells which were left to incubate for 10 minute at room temperature. After 10 minutes the medium was transferred to a 96-well plate and the absorbance read at $570 \mathrm{~nm}$ in a plate reader. The MTT assay relates the metabolic activity of the cells. In this assay MTT (yellow) is reduced to formazan (purple) and amount of colour change is indirectly related to cell number.

\section{RESULTS}

\subsection{Analysis of Surface Topography and Roughness}

Figure 3 shows the SEM and 3D white light interferometer images of EDM'ed and PMEDM'ed surfaces of the Ti6A14V work material. As observed, HA PMEDM'ed surfaces characterized by distinct features and morphologies compared to the EDMed surface in deionized water without powder addition. The EDM'ed surfaces (Figure 3(a) and Figure 4(a)) display formation of smooth molten materials with very shallow craters, which resulted in lower average surface roughness $\left(\mathrm{S}_{\mathrm{a}}\right)$ on the corresponding surface (Figure 5). With the HA powder addition to the dielectric liquid,complex porous microstructures composed of overlapped micro pits and decomposed HA powders embedded into the molten material, which could provide reliable anchorage for the particles and elements attached to the PMEDM'ed surfaces. More and deeper micro-craters were formed when HA 
concentration increased from 5 to $15 \mathrm{~g} / \mathrm{L}$, which led to high surface roughness, $\mathrm{S}_{\mathrm{a}}$ (mean areal surface roughness) and $\mathrm{S}_{z}$ (maximum height from valley to peak) as shown in Figure 5 and Figure 6, respectively, compared to polished and EDM'ed surfaces. The EDM'ed surfaces consisted of some microcracks (Figure4(a)) when treated with only deionized water. However, negligible or crack-free surfaces with porous structure were formed with HA PMEDM process (Figure 4(b-d)). Bruker 3D micrographs (Figure 3) also display micro roughness differentiation between different machining conditions. High concentration of HA led to increased micro roughness in micro-craters

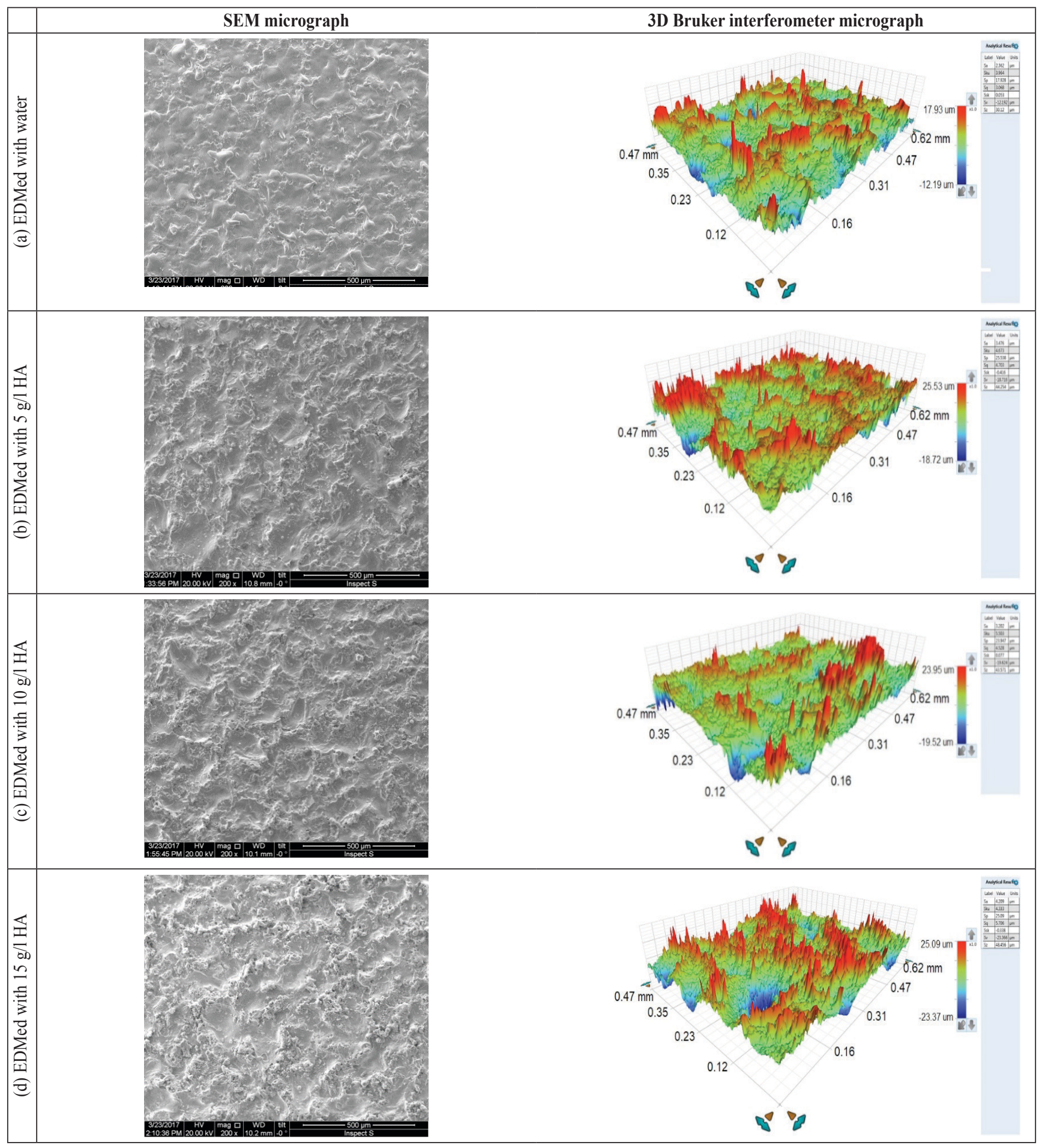

Figure 3.SEM and Bruker interferometer micrographs 


\subsection{Analysis of Surface Composition by EDS/XRD}

Element and phase composition of EDM'ed and PMEDM'ed surfaces were investigated using EDS and XRD analysis. Figure 7 shows an SEM image of the PMEDM'ed surface with $10 \mathrm{~g} / \mathrm{L}$ HA concentration. Associated EDS plot confirmed the presence of $\mathrm{Ti}, \mathrm{V}, \mathrm{Al}$, and $\mathrm{Ca}$ elements. The $\mathrm{Ca}$ elements are existing due to the chemical decomposition of the HA powder under a high thermal source of energy during sparking. Figure 8 shows the XRD patterns of the polished, EDM'ed and PMEDM'ed surfaces of Ti6Al4V samples. The phases are shown on the same graph to make a proper comparison. The polished Ti6Al4V sample contains more $\alpha$-Ti

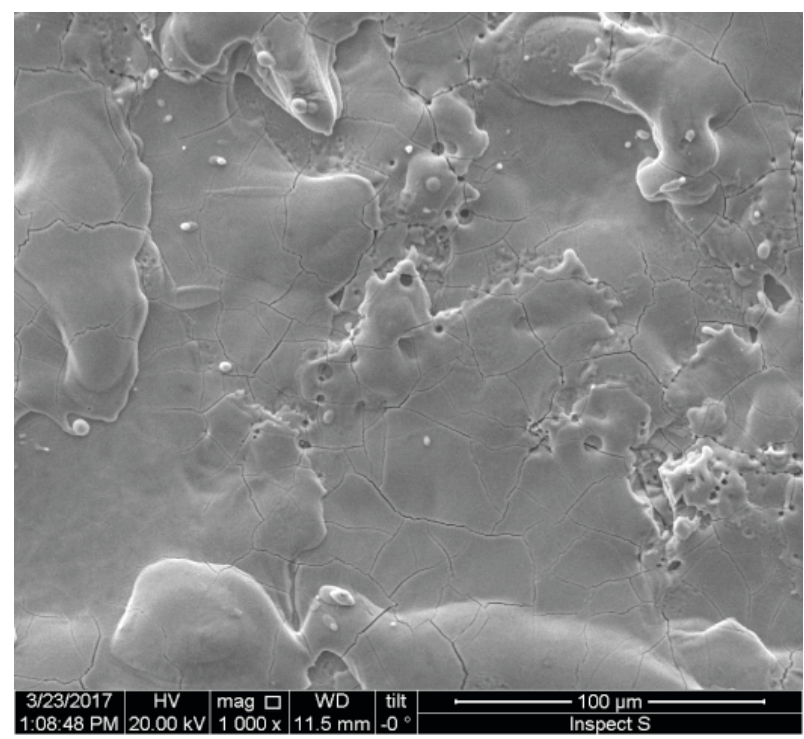

(a) EDMed with water

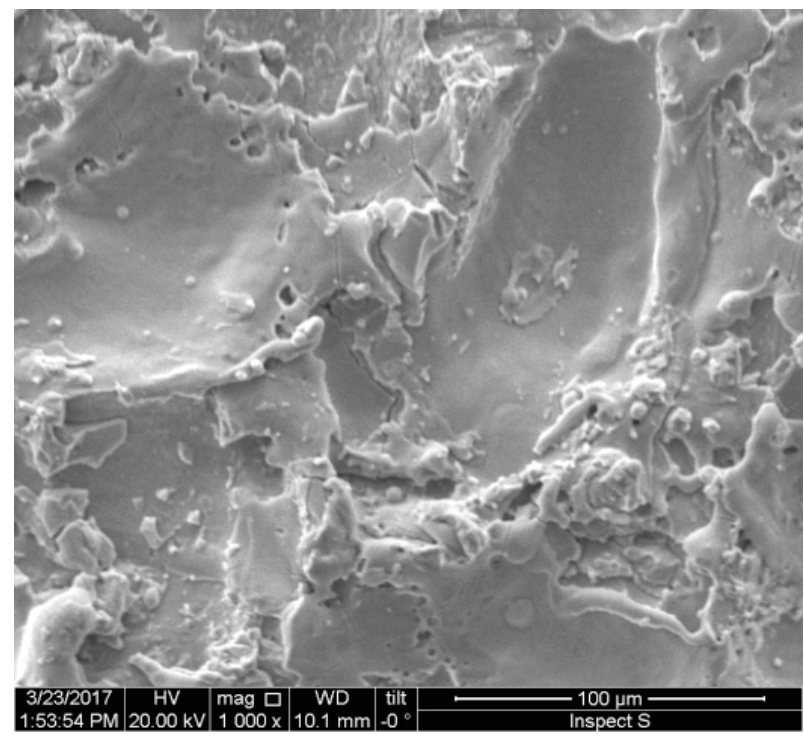

(c) EDMed with $10 \mathrm{~g} / \mathrm{l} \mathrm{HA}$ phases where the $\beta$-Ti peak is observed before the maximum $\alpha$-Ti at $40^{\circ}$. Samples which are machined in the water dielectric and HA mixed dielectric contain $\mathrm{TiO}$ phase where $\mathrm{O}$ diffused from water dielectric liquid during machining that improves surface biocompatibility and bone cells osseointegration characteristics. It is known that these bioceramics oxide layers have high corrosion resistance characteristics and commonly used as coating materials for biological application [19]. HA penetrating the surface during PMEDM are observed approximately at $36^{\circ}$ [18]. So, the presence of the HA-rich layer is confirmed that is crucial for medical applications.

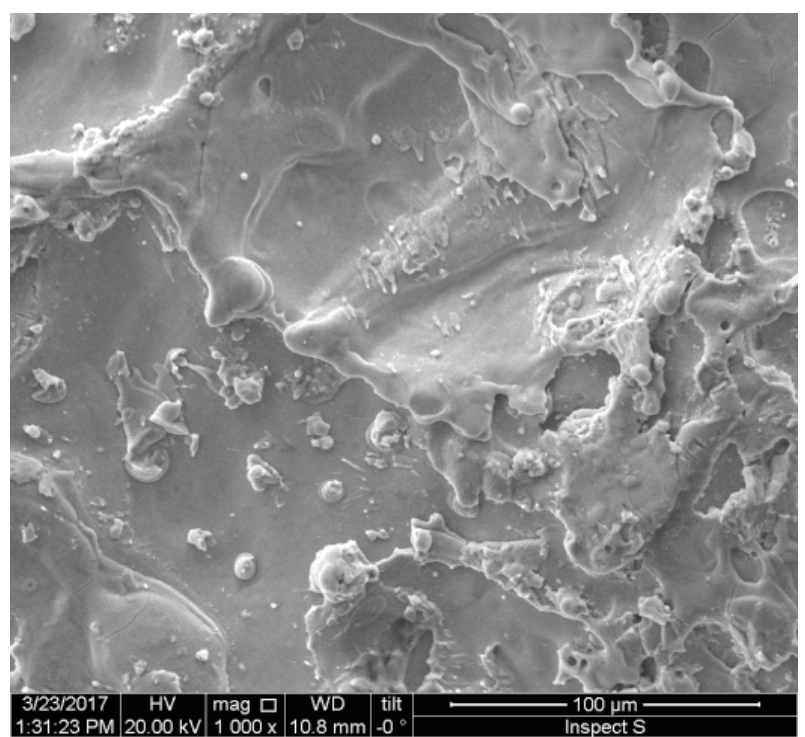

(b) EDMed with $5 \mathrm{~g} / \mathrm{l} \mathrm{HA}$

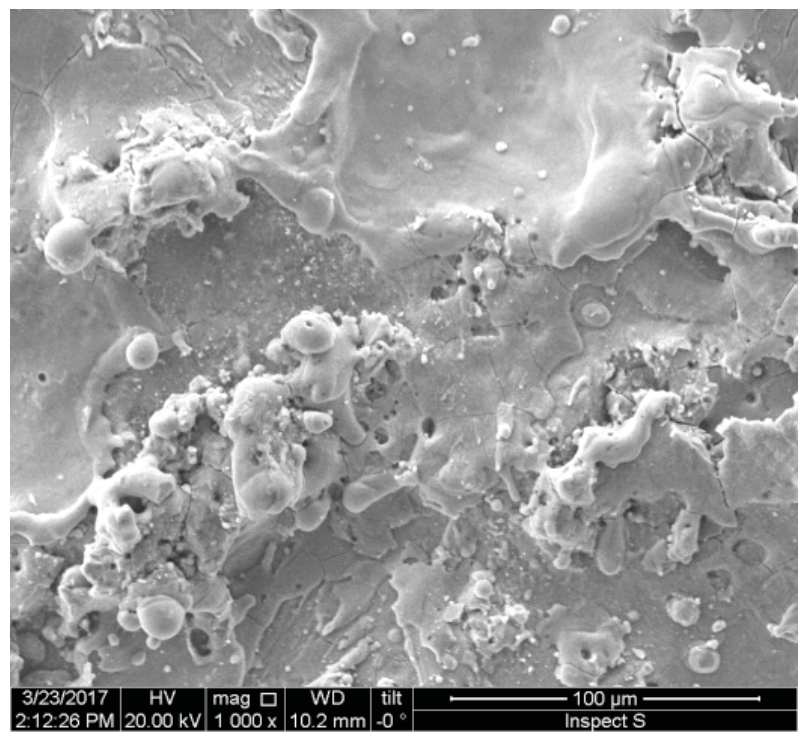

(d) EDMed with $15 \mathrm{~g} / 1 \mathrm{HA}$

Figure 4. SEM micrograph with 1000x magnification. 


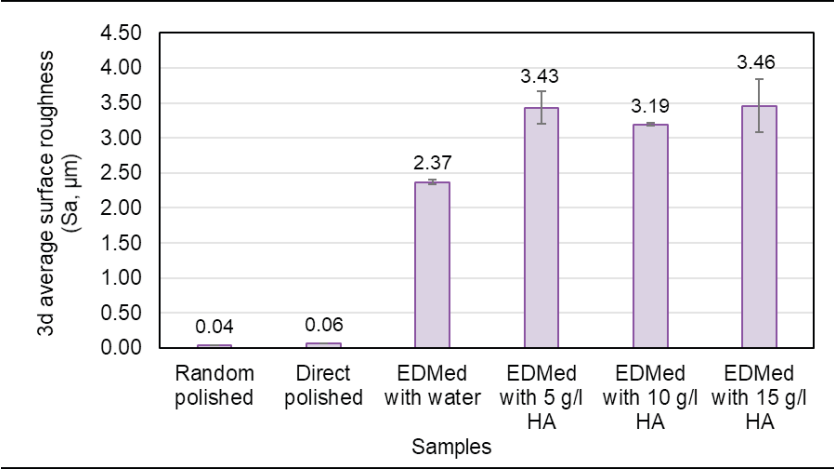

Figure 5. Average surface roughness (Sa) against samples treated by polishing and EDM and PMEDM.

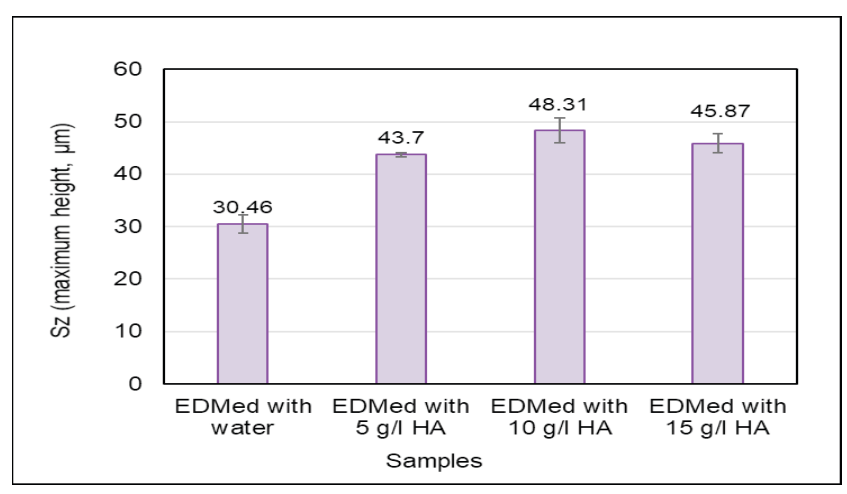

Figure 6.S measurement on EDM'ed and PMEDM'ed surfaces
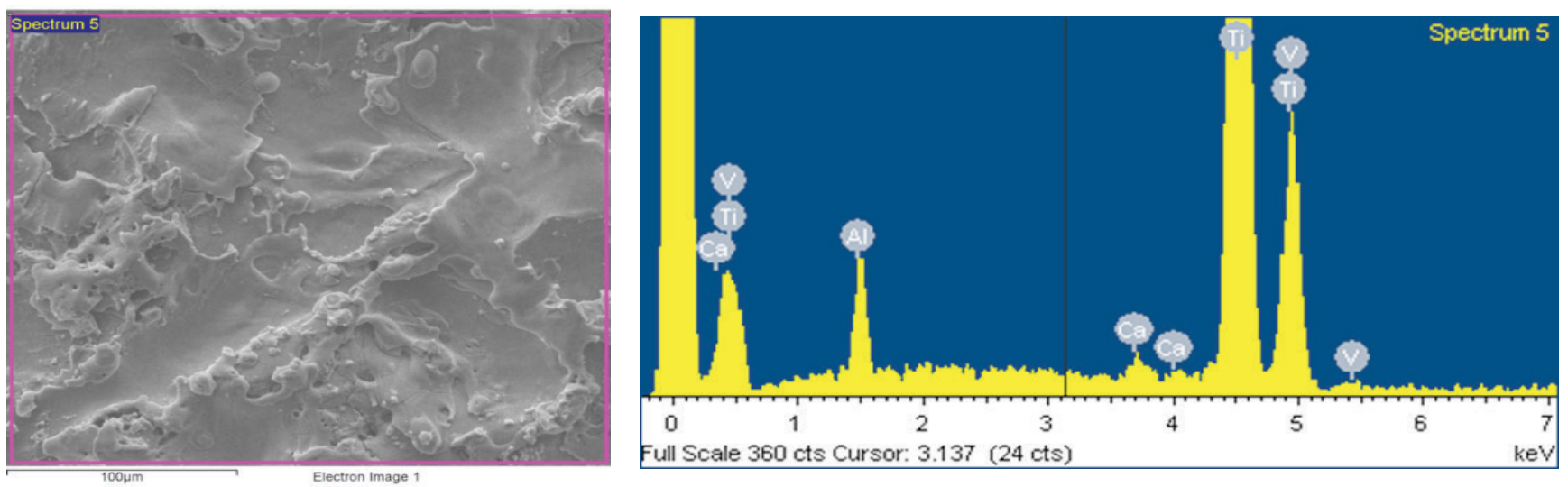

Figure 7. (a) SEM micrograph, (b) EDS analysis for samples EDM'ed with 10 g/l HA



Figure 8. XRD analysis of the sample surfaces. (a) Polished sample. (b) EDM'ed sample in water dielectric. (c) PMEDM'ed sample in 5 g/l HA (d) PMEDM'ed sample in $10 \mathrm{~g} / 1 \mathrm{HA}$ (e)

PMEDM'ed sample in $5 \mathrm{~g} / \mathrm{l} \mathrm{HA}$

\subsection{Surface Wettability}

The PMEDM was found to promote surface hydrophilicity due to high surface energy. Surface wettability was measured by using contact angle measurement technique. Figure 9 shows water drops on (a) the PMEDM'ed with $5 \mathrm{~g} / \mathrm{L} \mathrm{HA}$ and (b) polished surface, in which the contact angles measured from the drop shapes. The PMEDM'ed surfaces resulted in lower contact angles compared to EDM'ed and polished surfaces as shown in Figure 10. However, optimal HA concentration must be sought to give the most beneficial surfaces with super hydrophilicity characteristic, which requires further research on it. Thus, the lower the contact angle, the higher surface hydrophilicity. Surface hydrophilicity increases the adsorption of cell adhesion, which in turn contribute to promoting enhanced cell response, such as osteoblastic cell attachment and proliferation compared with hydrophobic Ti surfaces [29].

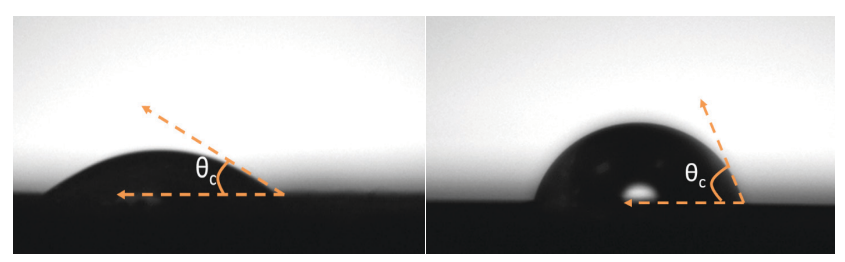

(a) EDM'ed with $5 \mathrm{~g} / 1 \mathrm{HA}$ (Contact angle $\left(\theta_{c}\right)=33.7^{\circ}$ )

(b) Random polished (Contact angle $\left.\left(\theta_{c}\right)=77.3^{\circ}\right)$

Figure 9. Contact angle measurement for wettability test. 


\subsection{Cell Attachment and Growth}

24 hours after the cells were seeded on to the surfaces, MTT assay was performed to determine the effect of EDM'ed and HA PMEDM'ed surfaces on cell adhesion and growth. Figure 11 shows adhesion/growth of the cells to PMEDM'ed with 10 and $15 \mathrm{~g} / \mathrm{L} \mathrm{HA}$ concentration give the best cell absorbance compared to that of the EDM'ed and polished surfaces. Higher the value of absorbance reflects that the given surfaces promoted cells attachment and growth. However, the polished surfaces give better cells absorbance compared to the EDM'ed and PMEDM'ed with $5 \mathrm{~g} / \mathrm{L}$ HA surfaces. These findings suggest that the HA PMEDM will be a promising alternative technique to modify the Ti alloys to promote the cells bioactivity and surface biocompatibility. Higher absorbance values with higher HA concentration could be attributed to surface porosity, rough microstructure, $\mathrm{Ca}$ elements and oxide phases ( $\mathrm{TiO})$ constituents created during the PMEDM.



Figure 10. Contact angle measurement for different surfaces.

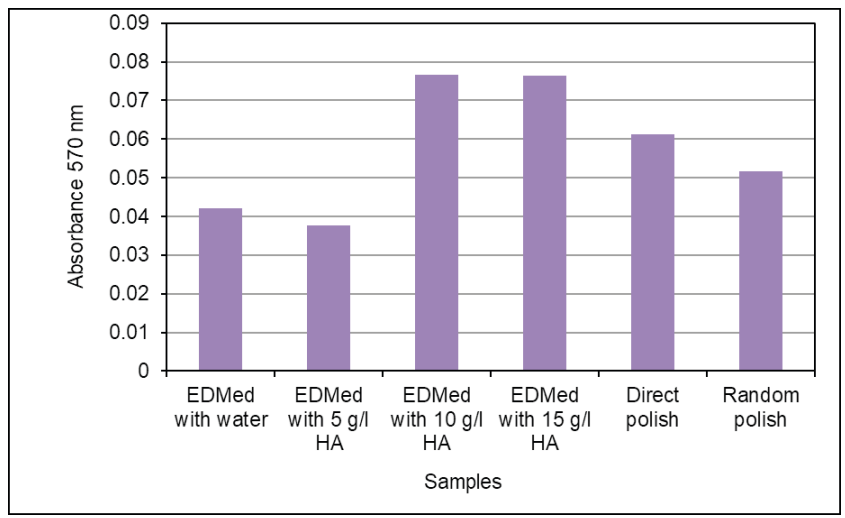

Figure 11. Surfaces were seeded with cells and left for $24 \mathrm{hrs}$. An MTT assay was carried out to determine relative attachment/ growth across all surfaces.

\section{DISCUSSION AND CONCLUSION}

The Ti6Al4V work material, often employed as an implant material in dental and orthopedic applications, was treated by the HA mixed EDM to investigate its surface formation characteristics and in vitro osteoblast-like MG-63 cells response to the generated surfaces. The HA mixed EDM'ed surfaces exhibit higher surface roughness compared to the control surfaces treated by abrasive polishing and EDM with deionized water. HA concentration in the dielectric fluid is one of the influential factors to obtain surfaces which can promote cellular activity and biocompatibility. Surface wettability, indicated by the water contact angle measurement, is also affected by the addition of HA powder. Highly hydrophilic surfaces with contact angles around $40^{\circ}$ were created by the HA mixed EDM compared to the polished surface with contact angle around $70^{\circ}$ and EDM'ed surface with contact angle around $62^{\circ}$. The hydrophilic surfaces promote cellular activity, which was observed in this work as well. The MTT assays demonstrate that better cell attachment and growth are observed and the surfaces treated by the HA ( $10 \mathrm{~g} / \mathrm{L}$ and $15 \mathrm{~g} / \mathrm{L}$ concentration) mixed EDM compared to all other surfaces. It is crucial to mention that the alteration on the surfaces with powder mixed EDM is partially due to alteration of the discharge mechanism, which resulted in several secondary discharges leading to particle migration and deposition. This discharge alteration phenomenon was detailed in the authors' previous paper [25]. It can be concluded that the HA mixed EDM with high HA concentration provides very efficient and rich surfaces for enhanced biocompatibility and improved cellular response. Factors affecting these improvements could be attributed to the formation of the HA-enriched layer composed of HA crystals and other elements $(\mathrm{Ca})$, oxide phases (such as $\mathrm{TiO}$ and $\mathrm{TiO}_{2}$ ), higher micro surface roughness, and hydrophilic surface characteristics. Further work could be needed to find optimal conditions including HA concentration to obtain better biocompatible surfaces, and further, in vitro, biological tests could be performed to investigate the cell adhesion, proliferation and differentiation on the HA mixed EDM'ed surfaces.

\section{REFERENCES}

[1] Chen, S. L., Lin, M. H., Chen, C. C., and Ou, K. L., (2008). Effect of electro-discharging on formation of biocompatible layer on implant surface. Journal of Alloys and Compounds, 456 (1-2), 413-418.

[2] Peng, P.-W., Ou, K.-L., Lin, H.-C., Pan, Y.-N., and Wang, C.H., (2010). Effect of electrical-discharging on formation of nanoporous biocompatible layer on titanium. Journal of Alloys and Compounds, 492 (1-2), 625-630. 
[3] Yang, T. Sen, Huang, M. S., Wang, M. S., Lin, M. H., Tsai, M. Y., and Wang Wang, P. Y., (2013). Effect of electrical discharging on formation of nanoporous biocompatible layer on Ti6Al-4V alloys. Implant Dentistry, 22(4), 374-379.

[4] Lee, W. F., Yang, T. Sen, Wu, Y. C., and Peng, P. W., (2013), "Nanoporous biocompatible layer on Ti-6Al-4V alloys enhanced osteoblast-like cell response. Journal of Experimental and Clinical Medicine, 5(3), 92-96.

[5] Lee, B. E. J., Ho, S., Mestres, G., Karlsson Ott, M., Koshy, P., and Grandfield, K., (2016). Dual-topography electrical discharge machining of titanium to improve biocompatibility", Surface and Coatings Technology. 296, 149-156.

[6] Murali, M., and Yeo, S. H., (2004). Rapid biocompatible micro device fabrication by micro electro-discharge machining. Biomedical Microdevices, 6(1), 41-45.

[7] Ntasi, A., Mueller, W. D., Eliades, G., and Zinelis, S., (2010). The effect of Electro Discharge Machining (EDM) on the corrosion resistance of dental alloys. Dental Materials, 26(12), 237-245.

[8] Uno, Y., Okada, A., and Cetin, S., (2001). Surface Modification of EDMed Surface with Powder Mixed Fluid. 2nd International Conference on Desing and Production of Dies and Molds.

[9] Furutani, K., Saneto, A., Takezawa, H., Mohri, N., and Miyake, H., (2001). Accretion of titanium carbide by electrical discharge machining with powder suspended in working fluid. Journal of the International Societies for Precision Engineering and Nanotechnology, 25, 138-144.

[10] Furutani, K., Sato, H., and Suzuki, M., (2009). Influence of electrical conditions on performance of electrical discharge machining with powder suspended in working oil for titanium carbide deposition process. International Journal of Advanced Manufacturing Technology, 40(11-12), 1093-1101.

[11] Janmanee, P., and Muttamara, A., (2012). Surface modification of tungsten carbide by electrical discharge coating (EDC) using a titanium powder suspension. Applied Surface Science, 258(19), 7255-7265.

[12] Kumar, S., and Batra, U., (2012). Surface modification of die steel materials by EDM method using tungsten powder-mixed dielectric. Journal of Manufacturing Processes, 14(1), 35-40.

[13] Yaşar, H., and Ekmekci, B., (2013). Ti-6Al-4V Surfaces in SiC Powder Mixed Electrical Discharge Machining. Advanced Materials Research, 856, 226-230.

[14] Jabbaripour, B., Sadeghi, M. H., Shabgard, M. R., and Faraji, H., (2013). Investigating surface roughness, material removal rate and corrosion resistance in PMEDM of $\gamma$-TiAl intermetallic. Journal of Manufacturing Processes, 15(1), 56-68.

[15] Amorim, F. L., Dalcin, V. A., Soares, P., and Mendes, L. A., (2017). Surface modification of tool steel by electrical discharge machining with molybdenum powder mixed in dielectric fluid. International Journal of Advanced Manufacturing Technology, 91(1-4), 341-350.
[16] Li, L., Zhao, L., Li, Z. Y., Feng, L., and Bai, X., (2017). Surface characteristics of Ti-6Al-4V by $\mathrm{SiC}$ abrasive-mixed EDM with magnetic stirring. Materials and Manufacturing Processes, 32(1), 83-86.

[17] Harcuba, P., Bačáková, L., Stráský, J., Bačáková, M., Novotná, K., and Janeček, M., (2012). Surface treatment by electric discharge machining of Ti-6Al-4V alloy for potential application in orthopedics. Journal of the Mechanical Behavior of Biomedical Materials, 7, 96-105.

[18] Chen, S. L., Lin, M. H., Huang, G. X., and Wang, C. C., (2014). Research of the recast layer on implant surface modified by micro-current electrical discharge machining using deionized water mixed with titanium powder as dielectric solvent. Applied Surface Science, 311, 47-53.

[19] Prakash, C., Kansal, H. K., Pabla, B. S., and Puri, S., (2015). Processing and Characterization of Novel Biomimetic Nanoporous Bioceramic Surface on b - Ti Implant by Powder Mixed Electric Discharge Machining. Journal of Materials Engineering and Performance, 24(9), 3622-3633.

[20] Prakash, C., Kansal, H. K., Pabla, B. S., and Puri, S., (2016). Powder Mixed Electric Discharge Machining: An Innovative Surface Modification Technique to Enhance Fatigue Performance and Bioactivity of $\beta$ - Ti Implant for Orthopedics Application. Journal of Computing and Information Science in Engineering, 16(4), 41006.

[21] Prakash, C., Kansal, H. K., Pabla, B. S., and Puri, S., (2016). Multi-objective optimization of powder mixed electric discharge machining parameters for fabrication of biocompatible layer on $\beta$-Ti alloy using NSGA-II coupled with Taguchi based response surface methodology. Journal of Mechanical Science and Technology, 30(9), 4195-4204.

[22] Prakash, C., Kansal, H. K., Pabla, B. S., and Puri, S., (2017). Experimental investigations in powder mixed electric discharge machining of $\mathrm{Ti}-35 \mathrm{Nb}-7 \mathrm{Ta}-5 \mathrm{Zr} \beta$-titanium alloy. $\mathrm{Ma}$ terials and Manufacturing Processes, 32(3), 274-285.

[23] Prakash, C., Kansal, H. K., Pabla, B. S., and Puri, S., (2017). On the Influence of Nanoporous Layer Fabricated by PMEDM on $\beta$-Ti Implant: Biological and Computational Evaluation of Bone-Implant Interface. Materials Today: Proceedings, 4(2), 2298-2307.

[24] Ekmekci, N., Ekmekci, B., (2013). Hydroxyapatite Deposition onto Ti-6Al-4V Surface in Powder Mixed Electrical Discharge Machining. 2nd International Conference on Material Science and Engineering Technology, London, The United Kingdom.

[25] Ekmekci, N. and Ekmekci, B., (2016). Electrical discharge machining of Ti6Al4V in hydroxyapatite powder mixed dielectric liquid. Materials and Manufacturing Processes, 31(13), 1663-1670.

[26] Prakash, C., and Uddin, M. S., (2017). Surface modification of $\beta$-phase Ti implant by hydroxyapatite mixed electric discharge machining to enhance the corrosion resistance and 
in-vitro bioactivity. Surface and Coatings Technology Part A, $326,134-145$.

[27] Ou, S. F., and Wang, C. Y., (2017). Effects of bioceramic particles in dielectric of powder-mixed electrical discharge machining on machining and surface characteristics of titanium alloys. Journal of Materials Processing Technology, 245, 70-79.

[28] Aliyu, A. A., Abdul-rani, A. M., Ginta, T. L., Prakash, C., Axinte, E., and Fua-nizan, R., (2017). Investigation of nanoporosities fabricated on metallic glass surface by hydroxyapatite mixed EDM for orthopedic application. Malaysian Journal of Fundamental and Applied Science Special Issue on Medical Device and Technology, 523-528.

[29] Otsuka, F., Kataoka, Y. and Miyazaki, T., (2012). Enhanced osteoblast response to electrical discharge machining surface. Dental Materials Journal, 31(2), 309-315. 